\title{
A JURISDIÇÃO PENAL ELEITORAL ENTRE A NORMATIVIDADE CONSTITUCIONAL E O "CANTO DA SEREIA": COMPETÊNCIA E COMPOSIÇÃO DA JUSTIÇA ELEITORAL BRASILEIRA APÓS A DECISÃO DO STF NOS AUTOS DO INQUÉRITO № 4435
}

\author{
The electoral criminal jurisdiction between constitutional normativity and \\ the "mermaid song": competence and composition of the Brazilian Electoral \\ Justice after the Supreme Court decision in the case of Inquiry n. 4435
}

\section{Guilherme Barcelos}

Resumo: O artigo destina-se a abordar, sob o prisma constitucional e legal, em sentido estrito, a controvérsia envolta à competência e à composição da Justiça Eleitoral após a decisão do Supremo Tribunal Federal (STF) lavrada nos autos do Inquérito $\mathrm{n}^{\circ}$ 4435/DF. Na referida decisão, o STF reafirmou que a competência para o julgamento dos crimes conexos aos crimes eleitorais é da Justiça Eleitoral. O conteúdo da decisão, apesar de não configurar novidade alguma, gerou uma cadeia de eventos que culminaram em diversas propostas de modificação da jurisdição penal eleitoral, especialmente naquilo que se refere às regras de competência e à composição da Justiça Eleitoral. O objetivo do texto reside, a partir da crítica hermenêutica do Direito, em demonstrar que tais investidas, calcadas não raramente em fundamentos não jurídicos, são inconstitucionais e ilegais em sentido estrito e, além disso, que se encontram direcionadas a foros decisórios inadequados, o que reforça a respectiva ilegalidade (constitucional e estrita). Para tanto, utilizaremos o método indutivo.

Palavras-chave: Justiça Eleitoral. Crimes Eleitorais. Crimes conexos. Competência. Composição. STF. Inquérito $\mathrm{n}^{\circ} 4435$.

\begin{abstract}
The article is intended to address, under the constitutional and legal prism, the controversy surrounding the competence and composition of the Electoral Justice after the decision of the STF drawn up in the records of Inquiry number 4435/DF. In that decision, the STF reaffirmed that the jurisdiction for the adjudication of crimes related to electoral crimes is of the Electoral Justice. The content of the decision, although not new, has generated a chain of events that culminated in several proposals to modify the electoral criminal jurisdiction, especially regarding the rules of competence and the composition of the Electoral Justice. The purpose of the text, based on the hermeneutic critique of law, is to demonstrate that such attacks, not infrequently based on non-legal grounds, are unconstitutional and illegal in the strict sense and, furthermore, that they are directed to inappropriate decision-making forums. reinforcing their illegality (constitutional and strict). For this, we will use the inductive method.
\end{abstract}

Keywords: Electoral justice. Electoral Crimes. Related crimes. Competence. Composition. Supreme Court. Investigation procedure number 4435. 


\section{Introdução}

O artigo destina-se a abordar, sob o prisma constitucional e legal, em sentido estrito, a controvérsia envolta à competência e à composição da Justiça Eleitoral após a decisão do Supremo Tribunal Federal (STF) lavrada nos autos do Inquérito nº-4435/DF. Na referida decisão, o STF reafirmou, por maioria de votos, que a competência para o julgamento dos crimes conexos aos crimes eleitorais é da Justiça Eleitoral. A relatoria do caso ficou a cargo do Ministro Marco Aurélio, que prolatou o voto condutor do julgado.

A corrente majoritária deu parcial provimento ao agravo interposto pela defesa do investigado e reafirmou o entendimento do Tribunal, desde há muito consolidado, no sentido de que a competência para o julgamento dos crimes conexos aos crimes eleitorais também é da Justiça Eleitoral. Ficaram vencidos os ministros Edson Fachin, Luís Roberto Barroso, Rosa Weber, Luiz Fux e Cármen Lúcia.

O conteúdo da decisão, apesar de não configurar novidade alguma, gerou uma cadeia de eventos que culminaram em diversas propostas de modificação da jurisdição penal eleitoral, especialmente naquilo que se refere às regras de competência e à composição da Justiça Eleitoral. Já o pano de fundo da "polêmica" dá conta da chamada "Operação Lava-Jato", sendo que o combustível para o assentamento de antagonismos injustificáveis - em razão da normatividade constitucional e da legislação infraconstitucional, além da tradição jurisprudencial do próprio STF - foi ofertado, dentre outros, por membros da "força-tarefa" (sic) da referida operação, procuradores do Ministério Público Federal (MPF) militantes na capital do Estado-federado do Paraná.

O próprio Tribunal Superior Eleitoral (TSE), por iniciativa da Presidência, criou grupo de trabalho com a finalidade de colher sugestões no sentido de fazer implementar a decisão do STF, o que foi formalizado por intermédio da portaria TSE no 231, de 22 de março de 2019.

Nesse contexto, ao fim e ao cabo, houve o surgimento de diversas propostas de modificação e/ou aperfeiçoamento da jurisdição penal eleitoral, especialmente naquilo que se refere às regras de competência e à composição da Justiça Eleitoral. Quanto à composição da Justiça Eleitoral, o deslocamento de juízes federais às zonas eleitorais é a proposta sustentada, por exemplo, pela Procuradoria Geral da República (PGR) e pela Associação dos Juízes Federais do Brasil (AJUFE). Já quanto à competência, ao 
menos dois Tribunais Regionais Eleitorais (TREs) do país tomaram medidas, por intermédio de Resoluções tendentes a "implementar" a comentada decisão do STF assentada nos autos do INQ n-4435. Trata-se, pois, dos TREs do Rio Grande do Sul e da Bahia. Essas investidas, a seu turno, fizeram criar zonas eleitorais específicas no âmbito dos respectivos territórios, às quais seriam incumbidas de processar e julgar, de forma especializada, crimes eleitorais conexos a crimes de corrupção ativa e passiva, de evasão de divisas, de lavagem ou ocultação de bens, direitos e valores, e os delitos praticados por organizações criminosas, independentemente do caráter transnacional ou não das infrações, e os pedidos de colaboração premiada e de cooperação jurídica passiva em matéria penal.

Procuraremos demonstrar, assim sendo, que tais investidas, especialmente essas duas, são inconstitucionais e ilegais em sentido estrito e, além disso, que se encontram direcionadas a ou efetivadas por foros decisórios inadequados. E, para tanto, o artigo será dividido em dois capítulos: no primeiro, será trazido à tona o conteúdo da decisão do STF; e, no segundo, será demonstrado como essas propostas vieram à arena pública, e os seus fundamentos, sendo perquirido como a Constituição e a legislação infraconstitucional tratam das matérias afetas à composição e à competência da Justiça Eleitoral brasileira, de modo a denunciarmos, portanto, a inconstitucionalidade e a ilegalidade estrita de investidas dessa natureza.

\section{A decisão do STF nos autos do Inquérito no 4435 - a competência da Justiça Eleitoral para julgar os crimes conexos aos crimes eleitorais}

O INQ n-4435 decorre de informação obtida em acordos de colaboração premiada firmados por executivos e ex-executivos do Grupo Odebrecht, ocasião na qual teria sido indicada a prática de diversos delitos penais e penais eleitorais por parte de políticos fluminenses entre os anos de 2010 e 2014. De acordo com os autos, a conduta supostamente cometida em 2010 diz respeito ao recebimento de $\mathrm{R} \$ 3$ milhões a pretexto da campanha eleitoral do então candidato Pedro Paulo (DEM-RJ) para deputado federal. Em 2012, a investigação se refere ao suposto recebimento por Eduardo Paes de $\mathrm{R} \$ 15$ milhões em doação ilegal da empreiteira no âmbito de contratos referentes às Olimpíadas de 2016, visando à sua reeleição à Prefeitura do Rio. Já o fato relativo a 2014 consistiria no recebimento de 
doação ilegal de aproximadamente $\mathrm{R} \$ 300$ mil para a reeleição de Pedro Paulo. O caso envolve a suposta prática de crimes de corrupção passiva, corrupção ativa, lavagem de capitais, evasão de divisas e falsidade ideológica eleitoral ${ }^{1}$.

O Plenário do Supremo Tribunal Federal (STF), nos autos do referido Inquérito e na data de 14 de março de 2019, refirmou a jurisprudência histórica da Corte no sentido de considerar como da alçada de competência da Justiça Eleitoral a prerrogativa de processar e julgar os crimes comuns que apresentam conexão com crimes eleitorais. Na mesma decisão, o STF assentou que caberia à Justiça especializada a análise, caso a caso, acerca da existência de conexão de crimes comuns a crimes eleitorais ou não, algo passível de análise apenas e tão somente à luz da facticidade dos casos concretos submetidos ao crivo da jurisdição penal eleitoral.

A matéria foi apreciada no julgamento de recurso (agravo regimental) interposto pela defesa do ex-prefeito do Rio de Janeiro, Eduardo Paes, e do deputado federal Pedro Paulo (DEM-RJ) no Inquérito (INQ) 4435, no qual são investigados por fatos supostamente ocorridos em 2010, 2012 e 2014. No agravo, os investigados pediram a manutenção da investigação no STF, tendo em vista que Pedro Paulo ocupava, na época da maior parte dos fatos, o cargo de deputado federal. Caso o processo não fosse mantido na jurisdição do STF, requereriam o encaminhamento do caso à Justiça Eleitoral fluminense ${ }^{2}$.

A corrente majoritária - formada pelos ministros Marco Aurélio (relator), Alexandre de Moraes, Ricardo Lewandowski, Gilmar Mendes, Celso de Mello e Dias Toffoli - deu parcial provimento ao agravo e reafirmou o entendimento do Tribunal. Ficaram vencidos os ministros Edson Fachin, Luís Roberto Barroso, Rosa Weber, Luiz Fux e Cármen Lúcia, que votaram pela cisão de parte da apuração entre a Justiça Eleitoral e a Justiça Federal.

\footnotetext{
${ }^{1}$ BRASIL. Supremo Tribunal Federal. Plenário do STF reafirma competência da Justiça Eleitoral para julgar crimes comuns conexos a delito eleitoral. Brasília-DF. Disponível em: http://www.stf.jus.br/portal/cms/verNoticiaDetalhe.asp?idConteudo=405834. Acesso em: 01 set. 2019.

${ }^{2}$ BRASIL. Supremo Tribunal Federal. Plenário do STF reafirma competência da Justiça Eleitoral para julgar crimes comuns conexos a delito eleitoral. Brasília-DF. Disponível em: http://www.stf.jus.br/portal/cms/verNoticiaDetalhe.asp?idConteudo=405834. Acesso em: 01 set. 2019.
} 
Em seu voto, o Ministro Marco Aurélio afirmou a competência da Justiça Eleitoral do Estado do Rio de Janeiro para processar e julgar as condutas delituosas supostamente cometidas em 2010 e 2012. Como em 2010, Pedro Paulo exercia cargo de deputado estadual, e não federal, o relator entendeu que o Supremo não era competente para analisar os fatos referentes ao período. Em relação aos delitos supostamente cometidos em 2012, concluiu que os fatos também não estão vinculados ao mandatode deputado federal. Com relação aos delitos supostamente praticados em 2014, o ministro Marco Aurélio reconheceu a competência do Supremo,pois Pedro Paulo já ocupava o cargo de deputado federal e os fatos apura-dos envolveriam sua reeleição ${ }^{3}$.

O Ministro Gilmar Mendes, por sua vez, acompanhando o voto do Relator, fez um histórico sobre o tratamento dado a todas as constituições brasileiras sobre a competência da Justiça Eleitoral. Ele avaliou que as Constituições de 1932, 1934, 1946, 1967 e 1969 reconhecem a competência da Justiça especializada para processar e julgar crimes eleitorais e conexos. "Isso demonstra uma continuidade normativa", ressaltou. Segundo ele, a Constituição de 1988 não tratou da questão de forma taxativa, mas o artigo 121 estabeleceu os casos submetidos à Justiça Eleitoral, seguindo a linha de raciocínio das cartas anteriores. $\mathrm{O}$ ministro explicou que a razão relevante para a atribuição de tal competência é a preocupação com o bom funcionamento das regras do sistema democrático e com a lisura dos pleitos eleitorais ${ }^{4}$.

O decano da Corte, ministro Celso de Mello, destacou em seu voto que a Segunda Turma do STF não tem promovido nenhuma inovação ao considerar a Justiça Eleitoral competente para atuar em casos semelhantes aos dos autos, mas apenas tem se limitado a reafirmar orientação do Tribunal. A jurisprudência da Corte tem sido muito clara já com base na Constituição da República, destacou. No mesmo sentido, também votou o ministro Ricardo Lewandowski.

\footnotetext{
${ }^{3}$ BRASIL. Supremo Tribunal Federal. Plenário do STF reafirma competência da Justiça Eleitoral para julgar crimes comuns conexos a delito eleitoral. Brasília-DF. Disponível em: http://www.stf.jus.br/portal/cms/verNoticiaDetalhe.asp?idConteudo=405834. Acesso em: 01 set. 2019.

${ }^{4}$ BRASIL. Supremo Tribunal Federal. Plenário do STF reafirma competência da Justiça Eleitoral para julgar crimes comuns conexos a delito eleitoral. Brasília-DF. Disponível em: http://www.stf.jus.br/portal/cms/verNoticiaDetalhe.asp?idConteudo=405834. Acesso em: 01 set. 2019.
} 
O presidente do STF, ministro Dias Toffoli, reiterou seus votos proferidos quando integrava a Segunda Turma e, conforme ressaltou, estão na linha da jurisprudência da Corte. "Todos aqui estamos unidos no combate à corrupção e em defesa da Justiça Eleitoral, que estará pronta para atuar", destacou.

O ministro Edson Fachin foi o primeiro a divergir [...]. Para ele, as apurações referentes aos fatos tanto de 2010 como de 2014 deveriam ser remetidas à Justiça Eleitoral e, em seu entendimento, não haveria razões para manter nenhum dos casos no STF. Segundo o ministro, os fatos apurados não têm qualquer vinculação com as atribuições do mandato de deputado federal, ainda que se refiram à reeleição para o cargo. Já quanto às investigações relacionadas a 2012, Fachin concordou com o relator sobre a incompetência do Supremo nesta parcela das apurações, mas divergiu com relação ao destino da investigação $0^{5}$.

O ministro Luís Roberto Barroso seguiu a divergência. No entanto, registrou seu entendimento sobre a matéria de forma mais abrangente. Segundo ele, a investigação em tais casos deve ser iniciada sob a supervisão da Justiça Federal, e somente no final deve ser definido o local de encaminhamento dos processos, a depender dos crimes envolvidos. Barroso exemplificou seu ponto de vista afirmando que, se houver somente o crime de falsidade ideológica eleitoral, o processo deve ser enviado para a Justiça Eleitoral e, se houver corrupção, deve permanecer na Justiça Federal. O ministro Luiz Fux também seguiu o voto do ministro Edson Fachin, mas registrou seu posicionamento no sentido de que a competência deve ser definida somente quando a investigação tiver sido finalizada, com a conclusão da imputação dos crimes pelo Ministério Público. A divergência também foi seguida pelas ministras Rosa Weber e Cármen Lúcia ${ }^{6}$.

Logo, por apertada maioria de seis votos a cinco, o STF reafirmou aquilo que vinha decidindo há décadas, isto é: a competência para processar e julgar os crimes conexos a crimes eleitorais também é da Justiça Eleitoral,

\footnotetext{
${ }^{5}$ BRASIL. Supremo Tribunal Federal. Plenário do STF reafirma competência da Justiça Eleitoral para julgar crimes comuns conexos a delito eleitoral. Brasília-DF. Disponível em: http://www.stf.jus.br/portal/cms/verNoticiaDetalhe.asp?idConteudo=405834. Acesso em: 01 set. 2019.

${ }^{6}$ BRASIL. Supremo Tribunal Federal. Plenário do STF reafirma competência da Justiça Eleitoral para julgar crimes comuns conexos a delito eleitoral. Brasília-DF. Disponível em: http://www.stf.jus.br/portal/cms/verNoticiaDetalhe.asp?idConteudo=405834. Acesso em: 01 set. 2019.
} 
conclusão alcançada não apenas a partir do texto constitucional de 1988 e do texto da legislação infraconstitucional vigente e válida - Código Eleitoral e leis esparsas, mas da própria história institucional do STF, construída ano após ano através da sua jurisprudência. A competência para avaliar a conexão existente em cada caso concreto, de mais a mais, também é da Justiça Eleitoral, disse o STF, cabendo, pois, a este ramo especializado do Poder Judiciário brasileiro, observado o direito/dever fundamental de motivação das decisões judiciais e o direito fundamental de todo e qualquer jurisdicionado a uma resposta adequada à Constituição ${ }^{7}$, avaliar, caso a caso, a existência ou não da referida conexão. Havendo, a competência será mantida com a Justiça Eleitoral. Não havendo, a própria Justiça Eleitoral determinará a cisão e, ato contínuo, remeterá os autos correspondentes ao órgão jurisdicional competente para que tome, assim sendo, as medidas cabíveis.

\section{A composição e a competência da Justiça Eleitoralem matéria penal vs. o "canto da sereia" - da inconstitucionalidade e da ilegalidade estrita da alocação de juízes federais em zonas eleitorais e da criação de zonas eleitorais "especializadas"}

Antes, uma pergunta: o que a Odisseia de Homero $^{8}$ tem a ver com tudo isso? Diretamente, absolutamente nada. Porém, aproximando Direito e Literatura, é possível traçar um estreito paralelo entre a realidade de Ulisses (ou Odisseu, para nós), o canto das sereias e algumas propostas e ações de entidades públicas e órgãos de classe desencadeadas tão logo noticiada a decisão do STF no INQ no ${ }^{\circ}$ 4435/DF.

Na Odisseia, Homero narra a travessia de Ulisses e de sua tripulação de Troia a Ítaca na Grécia. Tão logo finda a epopeica guerra entre gre-

\footnotetext{
${ }^{7}$ A esse respeito: STRECK, Lenio Luiz. ABBOUD, Georges; CARNIO, Henrique Garbellini; OLIVEIRA, Rafael Tomaz de. Introdução à teoria e à fillosofia do Direito. 3. ed. São Paulo: Revista dos Tribunais, 2015. TASSINARI, Clarissa. A atuação do Judiciário em tempos de Constitucionalismo Contemporâneo. Revista da Faculdade de Direito do Sul de Minas, Pouso Alegre, v. 28, n. 2, p. 32, jul./dez. 2012; STRECK, Lenio Luiz. Hermenêutica jurídica e(m) crise: uma exploração hermenêutica da construção do Direito. 11. ed. Porto Alegre: Livraria do Advogado, 2014.

${ }^{8}$ HOMERO. Odisseia. Tradução de Antônio Pinto de Carvalho. São Paulo: Ed. Abril, 1978.
} 
gos e troianos (a famosa guerra de Troia ${ }^{9}$ ), Ulisses é instruído pelos deuses a voltar imediatamente para o seu reino (Ítaca). Porém, fora da rota ordinária, a nau de Ulisses aproximou-se da ilha de Capri, uma ilha rochosa conhecida como a região das sereias. Estes seres, segundo narra história, carregavam o poder de hipnotizar os homens através dos seus cantos. E o encantamento advindo dos citados cantos acabaria por conduzir as embarcações aos rochedos da morte, de onde dificilmente poderiam escapar. Ulisses sabia que não poderia resistir a ele.

Ulisses ordenou aos seus marinheiros que o amarrassem ao mastro do barco, e que, em qualquer hipótese, só viessem a soltá-lo futuramente, não importando quaisquer ordens vindouras que ele próprio viesse a emitir em sentido oposto. A ordem era clara: ele só poderia vir a ser desatado quando tivessem concluído a passagem pela ilha. Resistir era quase impossível. Ciente dessa realidade, no fim das contas, Ulisses criou uma autorrestrição. E, desse modo, o rei de Ítaca pôde vencer o canto e o encanto das sereias.

$\mathrm{Na}$ alegoria presente na Odisseia, de Homero, o canto das sereias é um símbolo da sedução à qual o ser humano está submetido. E as amarras ou correntes de Ulisses, o mecanismo hábil a suspendê-las. Ulisses é amarrado ao mastro do seu barco. E, mesmo ciente do poderoso canto das sereias, mantém-se firme e resistente aos seus efeitos. Ao ordenar aos subordinados que o amarrassem ao mastro, ele reconhece as suas fragilidades enquanto humano que é. Logo, o Rei de Ítaca usa de um mecanismo externo para resistir, assim evitando cair na cilada do cantar das sereias da ilha de Capri. Este mecanismo representou justamente as amarras/correntes de Ulisses, o que acabou por possibilitar a limitação do poder das sereias. Ao ser amarrado, Ulisses contém-se, suspende os seus desejos, a sua vontade, enfim, o seu arbítrio, e, imune ao canto das sereias, se mantém fiel aos pré-compromissos firmados, seguindo, então, incorruptível ao soar dos cantos, o curso em direção ao seu recanto. Pois bem.

Tão logo noticiada a decisão do Supremo Tribunal Federal (STF) nos autos do INQ no-4435/DF, isso no sentido de reafirmar que a competência para processar e julgar os crimes conexos aos crimes eleitorais é da Justiça Eleitoral, o deslocamento de juízes federais às zonas eleitorais veio

\footnotetext{
${ }^{9}$ HOMERO. Ilíada. Tradução de Manuel Odorico Mendes. São Paulo: Ed. Abril, 2009.
} 
à baila como uma proposta formal defendida pela Procuradoria Geral da República (PGR) e pela Associação Nacional dos Juízes Federais (AJUFE).

A AJUFE, representada pelo seu Presidente juiz federal Fernando Marcelo Mendes, passou a defender o dispêndio de um reforço estrutural na Justiça Eleitoral, de modo que juízes federais também pudessem integrar a Justiça Eleitoral no âmbito das Zonas Eleitorais. Para a entidade, os juízes estaduais ficariam com a competência para o julgamento dos crimes eleitorais, enquanto os juízes federais passariam a possuir a competência para julgar os crimes conexos ${ }^{10}$.

A PGR, por sua vez, representada pela Procuradora-Geral da República, Raquel Dodge, passou a sustentar a mesma proposta em ofício remetido ao Tribunal Superior Eleitoral (TSE). Segundo a PRG, considerada a decisão do STF, seria indispensável a alteração da Resolução TSE $n^{0}$ 21.009/02, "[...] de forma a que sejam estabelecidos juízos especializados na Justiça Eleitoral para crimes eleitorais conexos a crimes de corrupção, de lavagem de dinheiro ou ocultação de bens, direitos e valores e praticados por organizações criminosas" ${ }^{11}$. Esse é o teor do Ofício nº 239 GAB/PGR.

A motivação das referidas propostas, é importante que se diga, recaiu numa diretriz central, qual seja "o combate à corrupção". Assim, segundo defenderam (e seguem defendendo) PRG e AJUFE "[...] o incremento de juízos eleitorais para processar crimes eleitorais associados à corrupção, lavagem ou ocultação de bens, direitos e valores e praticados por organizações criminosas, mostra-se a melhor via para o enfrentamento do influxo de ações penais complexas nessa temática para a Justiça Eleitoral"12. Nesse ínterim, no mais, não ignoremos o contexto subjacente que envolve a problemática: a (já citada) "Operação Lava-Jato" - munida de "porta-vo-

\footnotetext{
${ }^{10}$ Sobre o tema: BRASIL, Tribunal Superior Eleitoral. Audiência Pública colhe sugestões sobre decisão do STF. Brasília-DF. Disponível em: http://www.tse.jus.br/imprensa/noticias-tse/2019/Maio/audiencia-publica-colhe-sugestoes-sobre-decisao-do-stf. Acesso em: 02 set. 2019.

${ }^{11}$ BRASIL, Ministério Público Federal. Entidades defendem proposta da PGR para que juízes federais reforcem atuação em matéria eleitoral. Brasília-DF. Disponível em: http://www.mpf.mp.br/pgr/noticias-pgr/entidades-defendem-proposta-da-pgr-para-que-juizes-federais-reforcem-atuacao-em-materia-eleitoral. Acesso em: 02 set. 2019.

${ }^{12}$ BRASIL, Ministério Público Federal. Entidades defendem proposta da PGR para que juízes federais reforcem atuação em matéria eleitoral. Brasília-DF. Disponível em: http://www.mpf.mp.br/pgr/noticias-pgr/entidades-defendem-proposta-da-pgr-para-que-juizes-federais-reforcem-atuacao-em-materia-eleitoral. Acesso em: 02 set. 2019.
} 
zes" (sic) não raro vorazes na defesa de inúmeras medidas tendentes ao "combate à corrupção", sem que se faça a mínima digressão constitucional acerca das mesmas medidas (uma espécie de "vale-tudo", como se os fins justificasse os meios em matéria de Direito).

Ocorre que a proposta em comento é desabridamente inconstitucional, porquanto violadora do artigo 120, incisos I e II, da Constituição Federal (o dispositivo constitucional é categórico ao afirmar que as zonas eleitorais serão ocupadas por juízes de direito e, portanto, por juízes estaduais). E é ilegal, em sentido estrito, no mais, confrontando, na espécie, com os artigos 32 e 36 do Código Eleitoral (dispositivos legais que, regulamentando o texto constitucional, reafirmam a ocupação das zonas eleitorais por juízes de direito e, consequentemente, por juízes estaduais).

Trata-se, portanto, tais propostas, de uma tentativa escancarada de fazer soçobrar o texto constitucional e o texto infraconstitucional com lastro em argumentos de moral e de política, como se a defesa da coisa pública não devesse transcorrer dentro dos limites pré-estabelecidos pela ordem constitucional e legal vigente ou, diga-se de passagem, como se a decisão do STF representasse uma hecatombe, a ponto de a Justiça Eleitoral passar à vilã do indigitado "combate à corrupção" (sic). Além de inconstitucionais e ilegais em sentido estrito, tais falas são indelicadas, como se a Justiça Eleitoral não tivesse a menor capacidade de lidar com questões complexas como crimes de corrupção, lavagem de dinheiro etc. (segundo dão a entender);

Nesse exato sentido, cite-se a doutrina Roberta Maia Gresta, para quem a competência da Justiça Eleitoral "[...] para julgar crimes eleitorais e conexos a estes está prevista na lei. A decisão do STF é [...] tecnicamente correta"13.

Não é diferente a afirmativa de Fernando Neisser, segundo a qual

[...] Trata-se de uma frágil e ofensiva cortina de fumaça. Frágil, porque delegamos a esta mesma Justiça Eleitoral, com imenso sucesso, a realização das eleições no Brasil há mais de oitenta anos. Por qual razão delegaríamos a mais sensível missão de manutenção da nossa democracia a um órgão facilmente aparelhável por interesses políticos? Ofensiva, pois não só coloca sob suspeita as dezenas de

${ }^{13}$ GRESTA, Roberta Maia. Distorção semântica punitivistas não revoga competência da Justiça Eleitoral. Revista Consultor Jurídico. Conjur. Disponível em: https://www. conjur.com.br/2019-mar-19/roberta-gresta-congresso-corrigir-distorcao-codigo-eleitoral. Acesso em: 03 set. 2019. 
juízes e ministros dos tribunais eleitorais que vieram da advocacia, sem qualquer acusação sólida, mas por também estender tal crítica a toda magistratura brasileira. Talvez muitos não percebam, mas esse discurso aponta que só há três ou quatro varas aptas, probas e imparciais o suficiente para julgar corrupção no Brasil: em Curitiba, Rio de Janeiro, São Paulo e Brasília. E o restante dos milhares de juízes e dezenas de milhares de servidores do Poder Judiciário? Inaptos, incapazes, parciais? Por fim, cortina de fumaça, pois oculta os reais motivos por trás da proposta. A operação "lava jato" representa uma captura, por parte dos acusadores, sobre os julgadores. Quem acusa atua em parceria com quem julga, fazendo desaparecer a linha tão necessária que separa estas funções em uma democracia. O espírito punitivista, que só vislumbra sucesso em uma investigação se culminar em condenações, espraia-se para juízes, desembargadores e ministros que analisarão os processos, embalados em uma cobertura jornalística que compra e reverbera a lógica messiânica dos salvadores da pátria. E essa captura não há - e dificilmente haverá - no âmbito da Justiça Eleitoral. Exatamente por sua composição mista, trazendo diferentes visões de mundo para os julgamentos, torna-se muito difícil que caiam todos no enredo da inquisição ${ }^{14}$.

Ao lado da Militar, a Eleitoral é outra Justiça Especial. Não existe uma hierarquia entre a Justiça Militar e a Justiça Eleitoral, pois elas atuam em esferas distintas. Não se trata, assim, de prevalência, mas de cisão. Já na relação da Justiça Eleitoral com as Justiças Comuns (Federal e Estadual) existe uma prevalência da Especial sobre a Comum (art. 78, inc. IV, do CPP). Deve-se destacar que o artigo 78, IV, deve sempre ser lido junto com o art. 79, I, do CPP, para compreender-se que a Justiça Especial Eleitoral prevalece sobre as Justiças Comuns. A competência da Justiça Eleitoral está prevista no art. 121 da Constituição [...]. Sua competência, diante da lacunosa previsão constitucional, acaba sendo dada pelo Código Eleitoral, que prevê ainda quais são os crimes eleitorais. Assim, sempre que tivermos um crime eleitoral conexo com um crime comum, previsto no Código Penal, a competência para julgamento de ambos (reunião por força da conexão) será da Justiça Eleitoral (art. 78, IV) ${ }^{15}$.

\footnotetext{
${ }^{14}$ NEISSER, Fernando. "Lava jato" e a Justiça Eleitoral: transparência e imparcialidade nos argumentos. Revista Consultor Jurídico. Conjur. Disponível em: https://www.conjur.com. br/2019-mar-15/neisser-justica-eleitoral-competencia-julgar-lava-jato. Acesso em: 03 set. 2019. ${ }^{15}$ LOPES JR. Aury. Direito Processual Penal. 16. ed. São Paulo: Saraiva, 2019, p. 259.
} 
Já a composição das Zonas Eleitorais é efetivada com o assentamento único e exclusivo de juízes de Direito e, consequentemente, de juízes estaduais. Essa, aliás, sempre foi a orientação jurisprudencial tanto do STF quanto do TSE, muito antes da decisão assentada nos autos do INQ no 4435/DF, p. ex.: Ac.-TSE, de 29.3.2012, na Pet n 33275: impossibilidade de juízes federais integrarem a jurisdição eleitoral de primeiro grau.

Logo, considerada a competência da Justiça Eleitoral para processar e julgar os crimes conexos aos eleitorais, algo desde há muito consolidado, e considerada a composição da Justiça Eleitoral, é clarividente a inconstitucionalidade e a ilegalidade em sentido estrito das propostas em voga. Daí que a defesa da alocação de juízes federais em zonas eleitorais com lastro em argumentos de moral e demasiado abstratos nada mais representa, pois, do que o mencionado "canto da sereia", tão presente em matéria de Direito Eleitoral. Já as amarras de Ulisses representam, nesse mesmo contexto, a Constituição Federal, os seus princípios e as regras jurídicas (ambos normas) legitimadas pela principiologia constitucional. Isto é, as regras (e princípios) do jogo democrático.

A esse respeito, o voto do Ministro Celso de Mello nos autos do INQ n-4435/DF foi lapidar, ao afirmar que

[...] É na Constituição e na lei, e não na busca pragmática de resultados, independente de meios, que se deve promover o justo e o equilíbrio na tensão entre o princípio da autoridade de um lado e o valor de outro. O que se revela intolerável e não tem sentido é por divorciar-se do rule of law de que o respeito pela autoridade da Constituição e das leis possa traduzir frustração do processo penal ${ }^{16}$.

Qualquer iniciativa dessa natureza, no fim das contas, caberia ao Congresso Nacional, através do exercício do poder constituinte derivado, ao passo que eventual investida judicial, nesse sentido, mesmo que por intermédio do exercício do poder regulamentador inerente ao TSE, representaria, com o devido e merecido respeito, uma afronta ao princípio republicano, naquilo que se refere à separação de poderes, sem contar que a competência para legislar sobre Direito Penal, Direito Processual Penal,

\footnotetext{
${ }^{16}$ MELLO, Celso de. Citado por: ROVER, Tadeu. Decisão do Supremo sobre competên- cia da Justiça Eleitoral foi destaque. Revista Consultor Jurídico. Conjur. Disponível em: https://www.conjur.com.br/2019-mar-16/resumo-semana-decisao-supremo-competencia-justica-eleitoral-foi-destaque. Acesso em: 03 set. 2019.
} 
Direito Eleitoral e Direito Processual Eleitoral é da União (do Congresso Nacional; vide artigo 22, inciso I, da CF).

E não é distinta, ademais, a realidade envolta às propostas remanescentes desenvolvidas tão logo noticiada a mesma decisão objeto deste texto. Com efeito, ao menos dois Tribunais Regionais Eleitorais, por intermédio de Resoluções, teriam tomado medidas tendentes a implementar a comentada decisão do STF assentada nos autos do INQ nº-4435. Trata-se, pois, dos TREs do Rio Grande do Sul e da Bahia ${ }^{17}$.

A esse respeito, o TRE gaúcho fez publicar a Resolução TRE-RS no 326, de 08 de abril de 2019, que dispõe, por sua vez, acerca da “"...] designação específica da $2^{a}$ e da $160^{a}$ Zonas Eleitorais para processar e julgar, de for-ma especializada, crimes eleitorais conexos a crimes de corrupção ativa e passiva, de evasão de divisas, de lavagem ou ocultação de bens, direitos e valores,e os delitos praticados por organizações criminosas, independentementedo caráter transnacional ou não das infrações, os pedidos de colaboração premiada e de cooperação jurídica passiva em matéria penal, cria a Comissão de Assessoramento Criminal Especializado (CACE)", além de estabelecer outras providências. A referida Resolução, contando com doze artigos (dentre os quais os que mais nos interessam aqui são os artigos $1^{\circ}$ e o $2^{\circ}$ ) foi publicada no DEJERS, n. 64, p. 8, 09.04.2019, e republicada no DEJERS, n. 65 , p. $4,10.04 .2019$.

Sobre o tema, note-se que a redação contida no artigo $1^{\circ}$ da Res. TRE-RS no 326/19 fez designar, sem observância do sistema jurídico brasileiro, a $2^{\circ}$ e a $160^{\circ}$ Zonas Eleitorais para processar e julgar de forma especializada os crimes eleitorais e os crimes conexos previstos no respectivo texto:

Art. $1^{\mathrm{o}}$ Designar a $2^{\mathrm{a}} \mathrm{e}$ a $160^{\mathrm{a}}$ Zonas Eleitorais para processar e julgar de forma especializada, no âmbito da Justiça Eleitoral do Rio Grande do Sul, crimes eleitorais conexos a crimes de corrupção ativa e passiva, de evasão de divisas (Lei n. 7.492/1986), de lavagem ou ocultação de bens, direitos e valores (Lei n. 9.613/1998), e os delitos praticados por organizações criminosas (Lei n. 12.850/2013), independentemente do caráter transnacional ou não das infrações.

\footnotetext{
${ }^{17}$ A esse respeito, ver matéria no jornal Folha de São Paulo: "Justiça Eleitoral copia Lava-Jato para investigar casos de corrupção". BRASIL, Folha de São Paulo. 03 de maio de 2019. Disponível em: https://www1.folha.uol.com.br/poder/2019/05/justica-eleitoral-copia-lava-jato-para-investigar-casos-de-corrupcao.shtml. Acesso em: 03 set. 2019.
} 
Já o § $1^{\circ}$ do mesmo artigo $1^{\circ}$ da Res. TRE-RS 326/19 foi além, tudo para determinar que a designação anteriormente citada abrangeria as seguintes atuações:

$\S 1^{\circ} \mathrm{A}$ designação específica abrange o processamento e o julgamento de feitos envolvendo os delitos referidos no caput, tais como inquéritos policiais, procedimentos preparatórios, ações penais, medidas cautelares ou incidentais, autos de prisão em flagrante e audiências de custódia, mandados de segurança em matéria criminal, habeas corpus, pedidos de colaboração premiada e de cooperação jurídica em matéria penal, com ou sem intervenção de autoridade central ou expedição de carta rogatória, realizados ainda que de forma direta e informal, dentre outros expedientes.

O $\S 2^{\circ}$ artigo $1^{\circ}$ da Res. TRE-RS $n^{\circ} 326 / 19$, a seu turno, estabeleceu outra designação exclusiva às Zonas Eleitorais em comento, qual seja “[...] a atribuição jurisdicional de execução penal, sem prejuízo das demais atribuições, mediante distribuição igualitária dos processos". E o artigo $2^{\circ} \mathrm{da}$ mesma Res. TRE-RS n ${ }^{\circ} 3 z 6 / 19$, para fechar o cerco normativo formu-lado pela Corte Regional, passou a estabelecer que "[...] As zonas eleitorais designadas são consideradas zonas eleitorais especializadas em razão da matéria, $e$ terão competência sobre toda a Jurisdição Eleitoral do Rio Grande do Sul, qualquer que seja o meio, modo ou local de execução dos eventuais delitos".

Eis, ao fim e ao cabo, o estado d'arte em voga, isto é, a criação, por Resolução, de zonas eleitorais com competência especializada e exclusiva, com abrangência de atuação em todo o Estado-Federação, sem importar o local do cometimento do fato delituoso ou o domicílio do réu. Ambas as Zonas Eleitorais precitadas, aliás, encontram-se localizadas no Município de Porto Alegre, capital do Estado do Rio Grande do Sul. A inconstitucionalidade é patente, no entanto. Trata-se, a mais não poder, da criação de verdadeiros juízos de exceção, com todas as vênias de estilo.

Nesse ínterim, são três as inconstitucionalidades a serem denunciadas acerca da investida em xeque. A primeira é justamente a criação de juízos eleitorais de exceção, em clarividente desrespeito ao princípio constitucional (verdadeiro direito fundamental de todo e qualquer cidadão, de todo e qualquer jurisdicionado) do juiz natural, tal e qual a previsão constante do artigo 5, incisos XXXVII e LIII, da Constituição Federal - não haverá juízo ou 
tribunal de exceção, ninguém será processado nem sentenciado senão pela autoridade competente. A segunda inconstitucionalidade a ser denunciada a esse respeito, por sua vez, é a afronta ao princípio republicano, na vertente da separação de poderes, bem como a afronta ao princípio da legalidade ou da reserva legal $\left(\mathrm{CF}\right.$, arts. $1^{\circ}$ e $5^{\circ}$, inc. II), afinal, regras e competência processual penal se encontram estabelecidas por Resolução quando se trata de matéria tipicamente afeta à legislação. E a terceira inconstitucionalidade a ser denunciada, de mais a mais, é a afronta manifesta à competência da União para legislar sobre direito penal e direito processual penal, direito eleitoral e direito processual eleitoral, de acordo com a redação contida no artigo 20, inciso I, da CF.

Por fim, há outra intempérie que não deve ser ignorada, agora de índole de legalidade estrita: a afronta aos artigos 69 e 70 do CPP, naquilo que se refere à competência para processar e julgar crimes eleitorais. A competência para processar e julgar crimes eleitorais é do juízo do local onde o pretenso fato delituoso foi praticado ou, se assim for o caso, do juízo do local do domicílio do réu.

Desse modo, são patentes a inconstitucionalidade e a ilegalidade da referida Resolução do TRE-RS, naquilo que estabelece a competência especializada e exclusiva das duas Zonas Eleitorais sediadas em Porto Alegre, medida que vai de encontro ao juiz natural, ao princípio republicano, à competência legislativa da União e aos artigos 69 e 70 do CPP.

A defesa da alocação de juízes federais em zonas eleitorais, bem como a criação de Zonas Eleitorais especializadas, como fizeram os TRE da Bahia e do Rio Grande do Sul, nada mais representam, pois, do que o mencionado "canto da sereia", tão presente em matéria de Direito Eleitoral. Já as amarras de Ulisses representam, nesse mesmo contexto, a Constituição Federal, os seus princípios e as regras jurídicas (ambos normas) legitimadas pela principiologia constitucional. Isto é, as regras (e princípios) do jogo democrático.

Há que se lembrar sempre das amarras de Ulisses e compreender que a Constituição da República é una e a todos abarca, não se podendo, conseguintemente, contorná-la de maneira (e com fins) ad hoc. Deve-se agir por princípios, não pela moral, tampouco pela política. Agir por princípios, enfim, significa não ser consequencialista nos moldes da análise mo- 
ralista do direito (Streck). Casuísmos morais e políticos definitivamente não representam algo que se desenvolva na arena democrática ${ }^{18}$.

Nas dicções de Lenio Streck e outros, temos uma Constituição "que é o Alfa e o Ômega da ordem jurídica democrática. Uma Constituição dirigente e compromissória. Viver em uma democracia tem seus custos" 19 . Em suma: propugnando sempre pela preservação do grau de autonomia atingido pelo direito na democracia, pensamos que melhor mesmo é confiar na Constituição e na forma que ela mesma impõe para a sua alteração e a formulação de leis ${ }^{20}$.

Daí que, da mesma maneira, “[...] as Constituições funcionam como as correntes de Ulisses, através das quais o corpo político estabelece algumas restrições para não sucumbir ao despotismo das futuras maiorias (parlamentares ou monocráticas). Isso é de fundamental importância. Algo que os gregos ainda podem nos ensinar com a autoridade daqueles que forjaram o discurso democrático: entre eles, as decisões mais importantes acerca dos destinos da pólis só poderiam ser levadas a efeito no diálogo que se estabelecia na ágora"21. Mesmo nos momentos de desespero coletivo como ocorre em casos de Guerra, o que aparece claramente no texto de Homero - era necessário obedecer à razão e não às paixões temporárias ou aos interesses derivados das preferências pessoais de cada um dos indivíduos. E, como Ulisses e suas correntes, "também a democracia construída pelos gregos passava pelo desenvolvimento de mecanismos que limitavam

\footnotetext{
${ }^{18}$ BARCELOS, Guilherme. Ulisses e o canto das sereias: sobre o ativismo judicial eleitoral em terras brasileiras. Revista Jus Navigandi, ISSN 1518-4862, Teresina, ano 21, n. 4590, 25 jan. 2016. Disponível em: https://jus.com.br/artigos/45853. Acesso em: 03 set. 2019.

19 __ BARRETO, Vicente de Paulo; OLIVEIRA, Rafael Tomaz de. Ulisses e o Canto das Sereias: ativismos judiciais e o perigo da instauração de um "terceiro turno da Constituinte". Revista de Estudos Constitucionais, Hermenêutica e Teoria do Direito (RECHTD) 1(2): 75-83 julho-dezembro 2009, p. 2.

20 _. O que é decidir por princípios? A diferença entre a vida e a morte. Revista Consultor Jurídico. Conjur. Disponível em: <http://www.conjur.com.br/2015-ago-06/senso-incomum-decidir-principios-diferenca-entre-vida-morte>. Acesso em: 03 set. 2019.

21 __ BARRETO, Vicente de Paulo; OLIVEIRA, Rafael Tomaz de. Ulisses e o Canto das Sereias: ativismos judiciais e o perigo da instauração de um "terceiro turno da Constituinte". Revista de Estudos Constitucionais, Hermenêutica e Teoria do Direito (RECHTD) 1(2): 75-83 julho-dezembro 2009, p. 2.
} 
o exercício do poder e o racionalizavam. Enfim, mecanismos de pré-compromissos, ou de autorrestrição" 22 .

\section{Considerações finais}

$\mathrm{O}$ artigo destinou-se à uma análise crítica acerca da controvérsia envolta à competência e à composição da Justiça Eleitoral após a decisão do Supremo Tribunal Federal (STF) lavrada nos autos do Inquérito $\mathbf{n}^{\circ} 4435$ / DF. Na referida decisão, o STF reafirmou, por maioria de votos (6x5), que a competência para o julgamento dos crimes conexos aos crimes eleitorais é da Justiça Eleitoral.

O conteúdo da decisão, como demonstrado no curso do texto, apesar de não configurar novidade alguma, gerou uma cadeia de eventos que culminaram em diversas propostas de modificação da jurisdição penal eleitoral, especialmente naquilo que se refere às regras de competência e à composição da Justiça Eleitoral. Nesse contexto, ao fim e ao cabo, houve o surgimento de diversas propostas de modificação e/ou aperfeiçoamento da jurisdição penal eleitoral, especialmente naquilo que se refere às regras de competência e à composição da Justiça Eleitoral.

Quanto à composição da Justiça Eleitoral, o deslocamento de juízes federais às zonas eleitorais é a proposta sustentada, por exemplo, pela Procuradoria Geral da República (PGR) e pela AJUFE. Já quanto à competência, ao menos dois Tribunais Regionais Eleitorais do país, os TREs da Bahia e do Rio Grande do Sul, tomaram medidas, por intermédio de Resoluções, tendentes a "implementar" a comentada decisão do STF assentada nos autos do INQ no-4435.

Essas investidas, a seu turno, fizeram criar zonas eleitorais específicas no âmbito dos respectivos territórios, às quais seriam incumbidas de processar e julgar, de forma especializada, crimes eleitorais conexos a crimes de corrupção ativa e passiva, de evasão de divisas, de lavagem ou ocultação de bens, direitos e valores, e os delitos praticados por organizações criminosas, independentemente do caráter transnacional ou não das infrações, e os pedidos de colaboração premiada e de cooperação jurídica passiva em matéria penal. A competência das Zonas Eleitorais "especializadas" remontaria a todo território de cada um dos Estados-membros precitados.

22 . Ulisses e o Canto das Sereias: ativismos judiciais e o perigo da instauração de um "terceiro turno da Constituinte". Revista de Estudos Constitucionais, Hermenêutica e Teoria do Direito (RECHTD) 1(2): 75-83 julho-dezembro 2009, p. 2. 
A motivação das referidas propostas, procuramos evidenciar, no decorrer do artigo, recaiu numa diretriz central, qual seja, o "combate à corrupção". Nesse ínterim, no mais, não ignoremos o contexto subjacente que envolve a problemática: a (já citada) "Operação Lava-Jato" - munida de "porta-vozes" ( sic) não raro vorazes na defesa de inúmeras medidas tendentes ao "combate à corrupção", sem que se faça a mínima digressão constitucional acerca das mesmas medidas (uma espécie de "vale-tudo", como se os fins justificassem os meios em matéria de direito).

Ocorre que a proposta de alocação de juízes federais em zonas eleitorais, consoante demonstramos, é desabridamente inconstitucional, porquanto violadora do artigo 120, incisos I e II, da Constituição Federal (o dispositivo constitucional é categórico ao afirmar que as zonas eleitorais serão ocupadas por juízes de direito e, portanto, por juízes estaduais). E é ilegal, em sentido estrito, no mais, confrontando, na espécie, com os artigos 32 e 36 do Código Eleitoral (dispositivos legais que, regulamentando o texto constitucional, reafirmam a ocupação das zonas eleitorais por juízes de direito e, consequentemente, por juízes estaduais).

Ademais, não é distinta a realidade envolta às propostas remanescentes desenvolvidas tão logo noticiada a mesma decisão objeto deste texto. Com efeito, ao menos dois Tribunais Regionais Eleitorais, por intermédio de Resoluções, teriam tomado medidas tendentes a implementar a comentada decisão do STF assentada nos autos do INQ $\mathrm{n}^{\circ}$-4435. São três as inconstitucionalidades: a primeira é justamente a criação de juízos eleitorais de exceção ${ }^{23}$, em clarividente desrespeito ao princípio constitucional (verdadeiro direito fundamental de todo e qualquer cidadão, de todo e qualquer jurisdicionado) do juiz natural, tal e qual a previsão constante do artigo 5º, incisos XXXVII e LIII, da Constituição Federal; a segunda é a afronta ao princípio republicano, na vertente da separação de poderes, bem como a afronta ao princípio da legalidade ou da reserva legal $\left(\mathrm{CF}\right.$, arts. $1^{\circ}$ e $5^{\circ}$, inc. II), afinal, regras e competência processual penal se encontram estabelecidas por Resolução, quando se trata de matéria tipicamente afeta à legislação; e a terceira inconstitucionalidade é a afronta manifesta à competência da União

\footnotetext{
${ }^{23}$ A esse respeito, cite-se a doutrina de Antonio Scarance Filho: “[...] 1) só podem exercer jurisdição os órgãos instituídos pela Constituição; 2) ninguém pode ser julgado por órgão instituído após o fato; 3 ) entre os juízes pré-constituídos vigora uma ordem taxativa de competências que exclui qualquer alternativa deferida à discricionariedade de quem quer que seja". (SCARANCE, Antônio Fernandes. Processo penal constitucional. São Paulo: RT, 3. ed., 2002, p. 10.)
} 
para legislar sobre direito penal e direito processual penal, direito eleitoral e direito processual eleitoral, tudo de acordo com a redação contida no artigo 20, inciso I, da CF; por fim, outra intempérie não deve ser ignorada, agora de índole de legalidade estrita: a afronta aos artigos 69 e 70 do CPP, naquilo que se refere à competência para processar e julgar crimes eleitorais. A competência para processar e julgar crimes eleitorais é do juízo do local onde o pretenso fato delituoso foi praticado ou, se assim for o caso, do juízo do local do domicílio do réu.

Trata-se, portanto, tais propostas, de uma tentativa escancarada de fazer soçobrar o texto constitucional e o texto infraconstitucional com lastro em argumentos de moral e de política, como se a defesa da coisa pública não devesse transcorrer dentro dos limites pré-estabelecidos pela ordem constitucional e legal vigente ou, diga-se de passagem, como se a decisão do STF representasse uma hecatombe, a ponto de a Justiça Eleitoral passar à vilã do indigitado "combate à corrupção" (sic). Além de inconstitucionais e ilegais em sentido estrito, tais falas são indelicadas, como se a Justiça Eleitoral não tivesse a menor capacidade de lidar com questões complexas como crimes de corrupção, lavagem de dinheiro etc. (segundo dão a entender). Ou o Direito Eleitoral não seria matéria de alta especialização e complexidade.

Qualquer iniciativa dessa natureza, concluindo, caberia ao Congresso Nacional, através do exercício do poder constituinte derivado, ao passo que eventual investida judicial nesse sentido, mesmo que por intermédio do exercício do poder regulamentador inerente ao TSE, representaria, com o devido e merecido respeito, uma afronta ao princípio republicano, naquilo que se refere à separação de poderes, sem contar que a competência para legislar sobre Direito Penal, Direito Processual Penal, Direito Eleitoral e Direito Processual Eleitoral é da União (do Congresso Nacional; art. 22, inc. I, da CF).

A defesa da alocação de juízes federais em zonas eleitorais e a criação de Zonas Eleitorais especializadas, como fizeram os TRE da Bahia e do Rio Grande do Sul, nada mais representam, pois, do que o mencionado "canto da sereia", tão presente em matéria de Direito Eleitoral. Já as amarras de Ulisses representam, nesse mesmo contexto, a Constituição Federal, os seus princípios e as regras jurídicas (ambos normas) legitimadas pela principiologia constitucional. Isto é, as regras (e princípios) do jogo democrático. 
Há que se lembrar sempre das amarras de Ulisses e compreender que a Constituição da República é una e a todos abarca, não se podendo, conseguintemente, contorná-la de maneira (e com fins) ad hoc. Deve-se agir por princípios! Não pela moral, tampouco pela política. Agir por princípios, enfim, significa não ser consequencialista nos moldes da análise moralista do Direito (Streck). Casuísmos morais e políticos definitivamente não representam algo que se desenvolva na arena democrática.

\section{Referências}

BARCELOS, Guilherme. Ulisses e o canto das sereias: sobre o ativismo judicial eleitoral em terras brasileiras. Revista Jus Navigandi, ISSN 1518-4862, Teresina, ano 21, n. 4590, 25 jan. 2016. Disponível em: https://jus.com.br/ artigos/45853. Acesso em: 03 set. 2019.

BRASIL. Folha de São Paulo. 03 de maio de 2019. Disponível em: https:// www1.folha.uol.com.br/poder/2019/05/justica-eleitoral-copia-lava-jato-para-investigar-casos-de-corrupcao.shtml. Acesso em: 03 set. 2019.

. Supremo Tribunal Federal. Plenário do STF reafirma competência da Justiça Eleitoral para julgar crimes comuns conexos a delito eleitoral. Brasília-DF. Disponível em: http://www.stf.jus.br/portal/cms/verNoticiaDetalhe.asp?idConteudo=405834. Acesso em: 01 set. 2019.

. Ministério Público Federal. Entidades defendem proposta da PGR para que juízes federais reforcem atuação em matéria eleitoral. Brasília-DF. Disponível em: http://www.mpf.mp.br/pgr/noticias-pgr/entidades-defendem-proposta-da-pgr-para-que-juizes-federais-reforcem-atuacao-em-materia-eleitoral. Acesso em: 02 set. 2019.

. Tribunal Superior Eleitoral. Audiência Pública colhe sugestões

sobre decisão do STF. Brasília-DF. Disponível em: http://www.tse.jus.br/ imprensa/noticias-tse/2019/Maio/audiencia-publica-colhe-sugestoes-sobre-decisao-do-stf. Acesso em: 02 set. 2019.

GRESTA, Roberta Maia. Distorção semântica punitivistas não revoga competência da Justiça Eleitoral. Revista Consultor Jurídico. Conjur. Disponível em: https://www.conjur.com.br/2019-mar-19/roberta-gresta-congresso-corrigir-distorcao-codigo-eleitoral. Acesso em: 03 set. 2019. 
HOMERO. Odisseia. Tradução de Antônio Pinto de Carvalho. São Paulo: Ed. Abril, 1978.

. Ilíada. Tradução de Manuel Odorico Mendes. São Paulo: Ed. Abril, 2009.

LOPES JR. Aury. Direito Processual Penal. 16. ed. São Paulo: Saraiva, 2019.

MELLO, Celso de. Citado por: ROVER, Tadeu. Decisão do Supremo sobre competência da Justiça Eleitoral foi destaque. Revista Consultor Jurídico. Conjur. Disponível em: https://www.conjur.com.br/2019-mar-16/resumo-semana-decisao-supremo-competencia-justica-eleitoral-foi-destaque. Acesso em: 03 set. 2019.

NEISSER, Fernando. "Lava jato" e a Justiça Eleitoral: transparência e imparcialidade nos argumentos. Revista Consultor Jurídico. Conjur. Disponível em: https://www.conjur.com.br/2019-mar-15/neisser-justica-eleitoral-competencia-julgar-lava-jato. Acesso em: 03 set. 2019.

SCARANCE, Antônio Fernandes. Processo penal constitucional. 3. ed. São Paulo: RT, 2002.

STRECK, Lenio Luiz. Hermenêutica jurídica e(m) crise: uma exploração hermenêutica da construção do Direito. 11. ed. Porto Alegre: Livraria do Advogado, 2014.

ABBOUD, Georges; CARNIO, Henrique Garbellini; OLIVEIRA, Rafael Tomaz de. Introdução à teoria e à filosofia do Direito. 3. ed. São Paulo: Revista dos Tribunais, 2015.

. O que é decidir por princípios? A diferença entre a vida e a morte.

Revista Consultor Jurídico. Conjur. Disponível em: <http://www.conjur. com.br/2015-ago-06/senso-incomum-decidir-principios-diferenca-entre-vida-morte>. Acesso em: 03 set. 2019.

STRECK, Lenio Luiz; BARRETO, Vicente de Paulo; OLIVEIRA, Rafael Tomaz de. Ulisses e o Canto das Sereias: ativismos judiciais e o perigo da instauração de um "terceiro turno da Constituinte". Revista de Estudos Constitucionais, Hermenêutica e Teoria do Direito (RECHTD) 1(2): 75-83 julho-dezembro 2009. 
TASSINARI, Clarissa. A atuação do Judiciário em tempos de Constituciona- lismo Contemporâneo. Revista da Faculdade de Direito do Sul de Minas,Pouso Alegre, v. 28, n. 2, p. 32, jul./dez. 2012.

Guilherme Barcelos - Mestrado em Direito pela Universidade do Vale dos Sinos (UNI- SINOS/RS). Pós-Graduação em Direito Constitucional e em Direito Eleitoral. Gradu- ação em Direito pela Universidade da Região da Campanha (URCAMP/RS). MembroFundador da Academia Brasileira de Direito Eleitoral e Político (ABRADEP). Membro do Grupo de Pesquisa "Observatório Eleitoral" da Escola Superior de Direito Eleitoralda UERJ (ESDEL-UERJ/RJ). Parecerista da Revista "Ballot" da Escola Superior de Di-reito Eleitoral da UERJ (ESDEL-UERJ/RJ). Sócio Fundador da Barcelos Alarcon Advogados (Brasília/DF). Advogado. 